\title{
PERANCANGAN PEMBUATAN PERMEN KAPAS OTOMATIS BERBASIS ARDUINO UNO
}

\author{
Nurwijayanti Kusuma Ningrum ${ }^{1}$ \\ Program Studi Teknik Elektro Universitas Dirgantara Marsekal Suryadharma \\ Email: nurwijayanti_kn@yahoo.com \\ Fitriah $^{1}$ \\ Program Studi Teknik Elektro Universitas Dirgantara Marsekal Suryadharma \\ Email : rahma30.fitriah@gmail.com
}

\begin{abstract}
Cotton candy is one of Indonesia's traditional foods which was quite popular in its time. Cotton candy is made from sugar that is given food coloring, cotton candy is made using a special tool that rotates and produces refined sugar fibers. Most cotton candy consists of air cotton candy feels sweet and sticky. Even though it looks like wool yarn ... The design of this cotton candy maker uses an arduino uno microcontroller, equipped with a temperature sensor, 3 push buttons and a heating stove as a heating container for the sugar container design of this tool. All Arduino Uno microcontroller working systems have been programmed using the C program language on the Arduino Uno microcontroller. Using a dose of $1 / 2$ spoonful sugar, the average initial temperature $\left(54.5^{\circ} \mathrm{C}\right)$ and the average final temperature $\left(64.8^{\circ} \mathrm{C}\right)$ were obtained. Measuring one (1) spoonful of sugar, the initial heating temperature with an average $(68.80 \mathrm{C})$ average final temperature $(74.20 C)$. The dose of sugar 1 1/2 spoon, the initial temperature of the heater with an average $\left(70.4{ }^{\circ} C\right)$ the average temperature of the final heater (77.4). This tool takes time to heat the heating stove in approximately 2 minutes to reach ambient temperature $(54 o C)$. Testing to find out the exact time of each dose of sugar. as in the dose of half a sugar (1/2) a spoon an average of about 120 seconds is obtained, a dose of sugar (one) spoon is obtained an average time of about 150 seconds and in a sugar one and a half (11/2) spoon an average time is obtained about 180 seconds.
\end{abstract}

Keywords: Arduino Uno, LM35 Temperature Sensor, Relay, Cotton Candy

\begin{abstract}
ABSTRAK: Permen kapas adalah salah satu makanan tradisional khas Indonesia yang cukup populer pada masanya. Permen kapas dibuat dari gula yang diberi pewarna makanan, permen kapas dibuat menggunakan sebuah alat khusus yang berputar dan menghasilkan serat - serat gula yang halus. Sebagian besar permen kapas terdiri dari udara permen kapas terasa manis dan lengket. Meskipun terlihat seperti benang wol..Perancangan pembuat permen kapas ini menggunakan mikrokontroler arduino uno, dilengkapi sensor suhu, 3 buah push button dan kompor pemanas sebagai pemanas wadah penampung gula perancangan alat ini. Semua sistem kerja mikrokontroller arduino uno sudah diprogram menggunakan bahasa program $\mathrm{C}$ pada mikrokontroler Arduino Uno.Menggunakan takaran gula 1/2 sendok, didapatkan suhu awal rata-rata $\left(54,5^{\circ} \mathrm{C}\right)$ dan suhu akhir rata-rata $\left(64,8^{\circ} \mathrm{C}\right)$. Takaran gula satu (1) sendok, suhu awal pemanas dengan rata-rata $\left(68,8^{\circ} \mathrm{C}\right)$ suhu akhir rata-rata $\left(74,2^{\circ} \mathrm{C}\right)$. Takaran gula $11 / 2$ sendok, suhu awal pemanas dengan rata-rata $\left(70,4^{\circ} \mathrm{C}\right)$ suhu akhir pemanas rata-rata $(77,4)$. Alat ini membutuhkan waktu untuk memanaskan kompor pemanas dalam waktu kurang lebih 2 menit untuk mencapai suhu sekitar $\left(54^{\circ} \mathrm{C}\right)$. Pengujian untuk mengetahui waktu yang tepat dari setiap takaran gula. seperti pada takaran gula setengah (1/2) sendok diperoleh rata-rata waktu sekitar120 detik, takaran gula satu (1) sendok diperoleh rata-rata waktu sekitar150 detik dan pada takarang gula satu setengah $\left(1 \frac{1}{2}\right)$ sendok diperoleh rata-rata waktusekitar 180 detik.
\end{abstract}

Kata kunci : Arduino Uno, Sensor Suhu LM35, Relay, Permen Kapas

\section{PENDAHULUAN}

$\mathrm{P}$ ermen kapas adalah salah satu makanan tradisional khas Indonesia yang cukup populer pada masanya, ketika belum banyak permen atau lolipop kemasan seperti sekarang ini, anak-anak lebih menyukai membeli gulali yang dijual oleh pedagang keliling. Permen kapas dibuat dari gula yang diberi pewarna makanan, permen kapas dibuat menggunakan sebuah alat khusus yang berputar dan menghasilkan serat - serat gula yang halus. Sebagian besar permen kapas terdiri dari udara sehingga hasilnya seringkali besar, permen kapas terasa manis dan lengket. Meskipun terlihat seperti benang wol, permen kapas juga berubah menjadi lengket bila terkena uap air, karena gulanya bersifat higroskopis

Proses pembuatan permen kapas hanya menggunakan peralatan yang sederhana, alat pembuat permen kapas tradisional hanya menggunakan pemanas yang sederhana yang terdiri dari kompor kecil menggunakan minyak tanah atau spirtus, dengan pemutar manual yang harus digerakan oleh manusia sehingga mengakibatkan tangan manusia banyak bersentuhan dengan bahan atau wadah penampung permen kapas tersebut, yang menjadikan alat konvensional ini kurang higienis

\footnotetext{
${ }^{1}$ Program Studi Teknik Elektro Universitas Dirgantara Marsekal Suryadharma
} 
Proses pembuatan permen kapas hanya menggunakan peralatan yang sederhana, alat pembuat permen kapas tradisional hanya menggunakan pemanas yang sederhana yang terdiri dari kompor kecil menggunakan minyak tanah atau spirtus, dengan pemutar manual yang harus digerakan oleh manusia sehingga mengakibatkan tangan manusia banyak bersentuhan dengan bahan atau wadah penampung permen kapas tersebut, yang menjadikan alat konvensional ini kurang higienis.

Dalam penelitian ini akan dikembangkan proses pembuatan permen kapas otomatis dengan pembakaran gula menggunakan kompor listrik, untuk mengukur panas kompor tersebut menggunakan sensor suhu dan untuk mengatur waktu (timer) menggunakan Mikrokontroler Arduino Uno.

\section{TINJAUAN PUSTAKA}

\section{A. Arduino uno}

Arduino uno adalah board berbasis mikrokontroler pada ATmega328.Board ini memiliki 14 digital input / output pin (dimana 6 pin dapat digunakan sebagai output PWM), 6 input analog, $16 \mathrm{MHz}$ osilator kristal, koneksi USB,jack listrik tombol reset. Pin-pin ini berisi semua yang diperlukan untukmendukung mikrokontroler, hanya terhubung ke komputer dengan kabel USB atau sumber tegangan bisa didapat dari adaptor AC-DC atau baterai untuk menggunakannya. Board Arduino Uno memiliki fitur-fitur baru sebagai berikut : 1,0 pinout: tambah SDA dan SCL pin yang dekat ke pin aref dan dua pin baru lainnya ditempatkan dekat ke pin RESET, dengan IO REF yang memungkinkan sebagai buffer untuk beradaptasi dengan tegangan yang disediakan dari board sistem. Pengembangannya, sistem akan lebih kompatibel dengan Prosesor yang menggunakan AVR, yang beroperasi dengan $5 \mathrm{~V}$ dan dengan Arduino Karena yang beroperasi dengan 3.3V. Yang kedua adalah pin tidak terhubung, yang disediakan untuk tujuan pengembangannya.

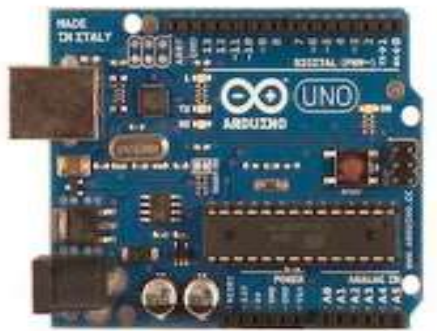

Gambar1. Board Arduino Uno

\section{B. Motor AC}

Motor AC adalah jenis motor listrik yang bekerja menggunakan tegangan AC (Alternating Current). Sebuah motor AC memiliki dua buah cincin slip sebagai pengganti komutator. Kedua cincin ini disambungkan ke ujung-ujung kumparan. Ketika kumparan berputar, tiap-tiap sikat akan teteap bersentuhan dengan sebuah cincin yang sama. Motor AC dapat bekerja dalam hubungan dengan tegangan sumber AC, sehingga konstruksi dari motor AC juga berbeda pada gulungan rotor maupun statornya. Pada kumparan statornya dibuat hanya satu fasa yang digulung sedemikian rupa, sehingga apabila dialiri dengan arus listrik akan membentuk kutub-kutub yang berpasangan. Sedangkan untuk rotornya digunakan rotor sangkar, yang apabila motor AC diberikan suatu sumber tegangan DC maka motor tidak akan dapat bekerja sebagaimana mestinya.

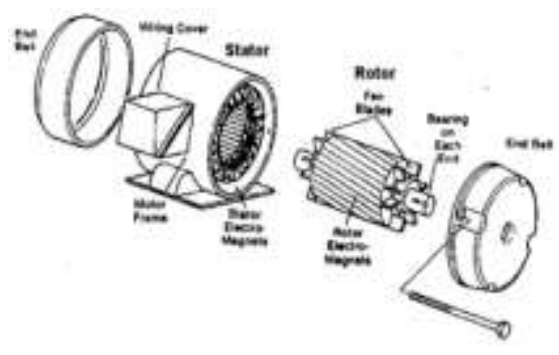

Gambar 2. Motor AC 


\section{Relay}

Relay adalah Saklar (Switch) yang dioperasikan secara listrik dan merupakan komponen Electromechanical (Elektromekanikal) yang terdiri dari 2 bagian utama yakni Elektromagnet (Coil) dan Mekanikal (seperangkat Kontak Saklar/Switch). Relay menggunakan Prinsip Elektromagnetik untuk menggerakkan Kontak Saklar sehingga dengan arus listrik yang kecil (low power) dapat menghantarkan listrik yang bertegangan lebih tinggi. Sebagai contoh, dengan Relay yang menggunakan Elektromagnet 5V dan $50 \mathrm{~mA}$ mampu menggerakan Armature Relay (yang berfungsi sebagai saklarnya) untuk menghantarkan listrik 220V 2A.

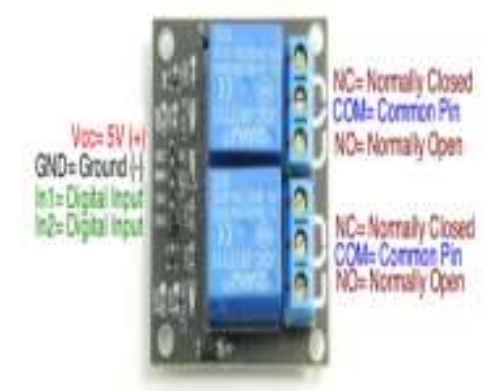

Gambar 3. Relay 2 Channel

Relay module 2 channel $5 \mathrm{~V}$ dengan 2 channel output dapat digunakan sebagai saklar elektronik untuk mengendalikan perangkat listrik yang memerlukan tegangan dan arus yang besar. Kompatible dengan semua mikrokontroler khususnya Arduino.

\section{Adaptor}

Adaptor adalah sebuah rangkaian yang berguna untuk mengubah tegangan AC yang tinggi menjadi DC yang rendah. Adaptor merupakan sebuah alternatif pengganti dari tegangan DC (seperti baterai,Aki) karena penggunaan tegangan AC lebih lama dan setiap orang dapat menggunakannya . Seperti yang kita tahu bahwa arus listrik yang kita gunakan di rumah, kantor dll, adalah arus listrik dari PLN ( Perusahaan Listrik Negara ) yang didistribusikan dalam bentuk arus bolak-balik atau AC.

\section{E. LCD (Liquid Crystal Display)}

LCD adalah singkatan dari kata (Liquid Crystal Display, yaitu panel penampil yang dibuat dari bahan kristal cair. Kristal dengan sifat-sifat khusus yang menampilkan warna lengkap yang berasal dari efek pantulan/transmisi cahaya dengan panjang gelombang dari sudut lihat tertentu. Pada dasarnya secara garis besar efek cahaya pada penyususn LCD dapat dideskripsikan sebagai berikut, operasi PDLC (Poliymer Dispersed Liquid Crystal) pada keadaan transparan (Pixel Kiri) dan pada keadaan hamburan (Pixel Knana).

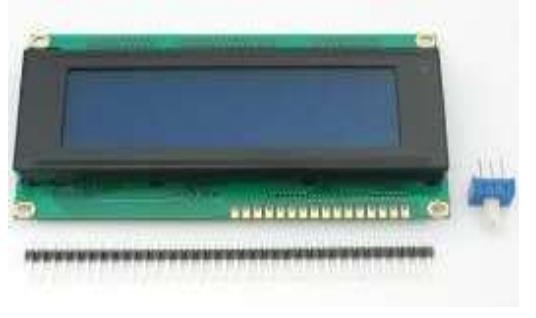

- Gambar 4. LCD

Dengan mikrokontroler kita dapat mengendalikan suatu peralatan agar dapat bekerja secara otomatis. Untuk mengakses LCD 20x4 harus melakukan konfigurasi pin. Fungsi LCD (Liquid Cristal Display) adalah jenis media tampilan yang menggunakan kristal cair sebagai tampilan suatu data, baik karakter, huruf ataupun grafik. bentuknya tipis, mengeluarkan sedikit panas, dan memiliki resolusi tinggi. LCD (Liquid Cristal Display) adalah salah satu jenis display elektronik yang dibuat dengan 
teknologi CMOS logic yang bekerja dengan tidak menghasilkan cahaya tetapi memantulkan cahaya yang ada di sekelilingnya terhadap front-lit atau mentransmisika cahaya dari back-lit.

\section{F. Kompor Pemanas (Pemanas Induksi)}

Pemanas Induksi merupakan salah satu produk teknologi yang sudah lama dibuat dan digunakan didalam industri maupun rumah tangga. Teknologi yang digunakan di dalam peralatan ini terus berkembang dari masa ke masa. Salah satu bentuk pemanas induksi yang kita temukan dalam kehidupan sehari-hari adalah Kompor Induksi. Pemanas Induksi (Induction Heating) pada prinsipnya dapat dijelaskan dengan prinsip kerja transformator. Transformator bekerja karena adanya fenomena induksi elektromagnetik yang mana ketika ada suatu rangkaian tertutup yang di dalamnya mengalir arus AC menghasilkan medan elektromagnetik yang berubah-ubah. Pada pembuatan alat ini menggunakan kompor pemanas yang menggunakan kipas (fan) diatasnya kipas (fan) berukuran sedang yang terbuat dari akrilik, Fungsi dari kipas (fan) tersebut untuk menghantarkan hawa panas dari pemanasnya untuk ditiup keatas.

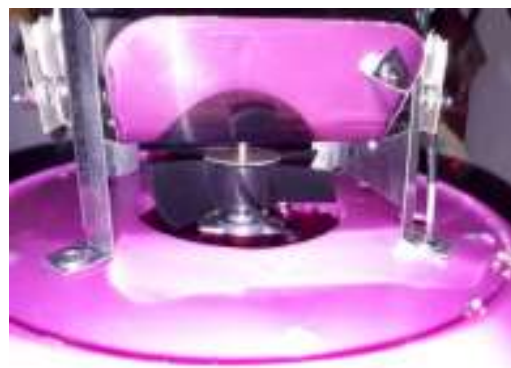

Gambar 5. Kompor Pemanas dan Kipas

\section{G. Push Button Switch}

Push button switch (saklar tombol tekan) adalah perangkat atau saklar sederhana yang berfungsi untuk menghubungksn/memutuskan aliran arus listrik dengan system kerja tekan unlock (tidak mengunci). System kerja unlock disini berarti saklar akan bekerja sebagai device penghubung atau pemutus aliran arus listrik saat tombol ditekan, dan saat tombol tidak ditekan (dilepas) maka saklar akan kembali pada kondisi normal.

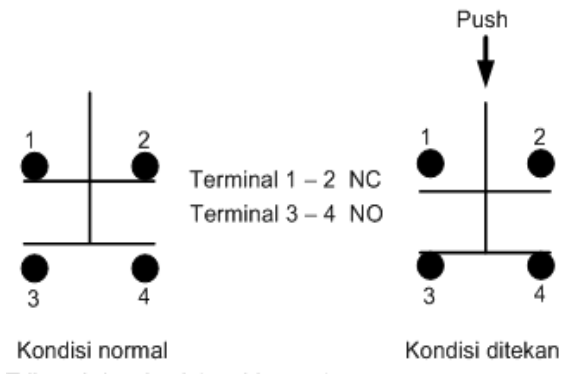

Gambar 6. Prinsip Kerja PB

Berdasarkan fungsi kerjanya yang menghubungkan dan memutuskan, push button switch mempunyai 2 tipe kontak yaitu NC (Normally Close) dan NO (Normally Open). NO (Normally Open) merupakan kontak terminal dimana kondisi normalnya terbuka (aliran arus listrik tidak mengalir), dan ketika tombol saklar ditekan kontak yang NO akan menjadi menutup (Close) dan mengalirkan/menyalakan sistem circuit (Push Button ON). NC (Normally Close) merupakan kontak terminal dimana kondisi normalnya tertutup (mengalirkan arus listrik) dan ketika tombol saklar push bootton ditekan, kontak NC akan menjadi membuka (Open) sehingga memutus aliran arus listrik. Kontak NC digunakan sebagai pemutus atau mematika circuit (Push Button Off).

\section{H. Alat Penukar Panas (Heat Exchanger)}

Adalah alat yang digunakan untuk memindahkan panas dari system kesistem lain tanpa perpindahan massa dan bisa berfungsi sebagai pemanas maupun sebagai pendingin. Panas adalah salah satu bentuk energi yang dapat dipindahkan dari suatu tempat ketempat lain, tetapi tidak dapat 
diciptakan atau dimusnakan sama sekali. Dalam suatu peroses, panas dapat mengakibatkan terjadinya kenaikan suhu suatu zat dan atau perubahan tekanan, reaksi kimia dan kelistrikan. Proses terjadi perpindahan panas dapat dilakukan secara langsung. Perpindahan panas secara konduksi merupakan perpindahan panas antara molekul-molekul yang saling berdekatan antara yang satu dengan yang lainnya dan tidak diikuti oleh perpindahan molekul-molekul tersebut secara fisik. Molekul-molekul benda yang panas bergetar lebih cepat dibandingkan molekul-molekul benda yang berada dalam keadaan dingin. Getaran-getaran yang cepat ini, tenaganya dilimpahkan kepada molekul di sekelilingnya sehingga menyebabkan getaran yang lebih cepat maka akan menghasilkan panas. Perpindahan panas secara konveksi perpindahan panas dari suatu zat ke zat yang lain disertai dengan gerakan partikel atau zat tersebut secara fisik. Perpindahan panas secara radiasi ialah perpindahan panas tanpa melalui media (tanpa melalui molekul).

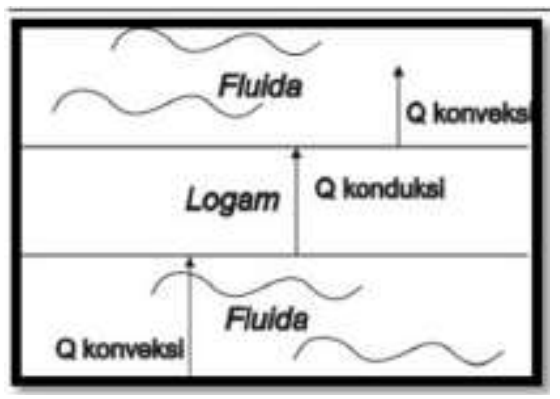

- Gambar 7. Perpindahan Kalor pada Heat Exchanger

\section{Kalor Jenis}

Kalor adalah salah satu bentuk energy yang dapat berpindah dari suatu benda ke benda yang lain. Kalor juga dapat diberikan kepada suatu benda atau diambil dari benda tersebut. Kolor dapat diberikan pada suatu benda dengan menggunakan cara pemanasan dan sebagai salah satu dampak yaitu kenaikan suhu benda tersebut. Kapasitor kalor adalah jumlah kalor yang diserap oleh benda bermassa tertentu untuk menaikan suhu sebesar $1^{\circ} \mathrm{C}$. satuan kapasistas kalor dalam sisitem internasional adalah $\mathrm{J} / \mathrm{K}$.

Rumus laju kalor yaitu :

Laju Kalor $=Q=m \cdot c \cdot \Delta t$

$$
\Delta t=T 2-T 1 Q=m \cdot c \cdot(T 2-T 1)
$$

Dimana

$$
Q=\text { Perpindahan Panas (joule) }
$$

$m=$ Massa Jenis $(g r)$

$$
\begin{aligned}
& c=\text { Kalor Jenis }\left(\frac{j}{\mathrm{~kg}}\right) \\
& \Delta t=\text { Perubahan Suhu }
\end{aligned}
$$

\section{J. Pengertian Interface}

Interface (antarmuka) adalah mekanisme komunikasi antara pengguna dengan sistem. Interface (antarmuka) dapat menerima informasi dari pengguna dan memberikan informasi kepada pengguan untuk membantu mengarahkan alur penelusuran masalah sampai ditemukan suatu solusi.

Interface (antarmuka) dapat berfungsi untuk menginput pengetahuan baru ke dalam basis pengetahuan sistem, dan menampilkan penjelasan sistem dan memberikan panduan pemakaian sisitem secara menyeluruh atau step by step sehingga pengguna mengerti apa yang akan dilakukan terhadap suatu sistem. Interface yang ada untuk berbagai sistem, input memungkinkan pengguna untuk memenipulasi sistem dan output memungkinkan sisitem untuk menunjukan efek manipulasi pengguna. 


\section{METODOLOGI PENELITIAN}

A. Blok Diagram

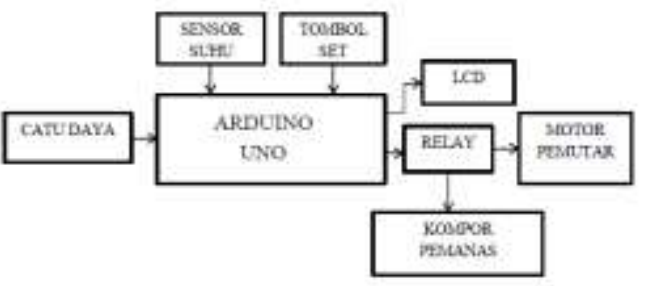

Gambar 8. Blok Diagram Sistem

Berdasarkan dari gambar diatas dapat dilihat system kerja pembuat permen kapas otomatis

a. Bagian input terdiri dari catu daya, sensor suhu untuk mendeteksi kondisi kompor pemanas apakah sudah menyala dan suhunya sudah cukup, lalu tombol yang digunakan untuk set lamanya waktu motor putaran berputar

b. Bagian output terdiri dari display LCD untuk menampilkan informasi kondisi suhu, kondisi putaran dan waktu putaran, lalu kompor pemanas yang terhubung melalui relay yang digunakan untuk memanaskan piringan yang berputar yang akan ditaruh gula pasir, lalu motor pemutar yang juga terhubung melalui relay baru terhubung ke arduino, digunakan untuk memutar gula yang sudah diletakkan di dalam piringan dan sudah dipanaskan.

B. Flowchart Kerja Sistem

Flowchart dari alat ini dapat dilihat pada gambar dibawah ini

Penjelasan dari gambar diatas :

1. Pertama kali sistem selalu menunggu tombol ditekan jadi tidak mungkin sistem berjalan tanpa ada trigger

2. Jika tombol OK ditekan setelah sudah pilih waktu lamanya putaran, maka kompor pemanas mulai bekerja

3. Lalu tempat meletakkan gula mulai berputar

4. Setelah waktu yang sudah ditentukan selesai, kompor pemanas off

5. Tempat meletakkan gula berhenti berputar

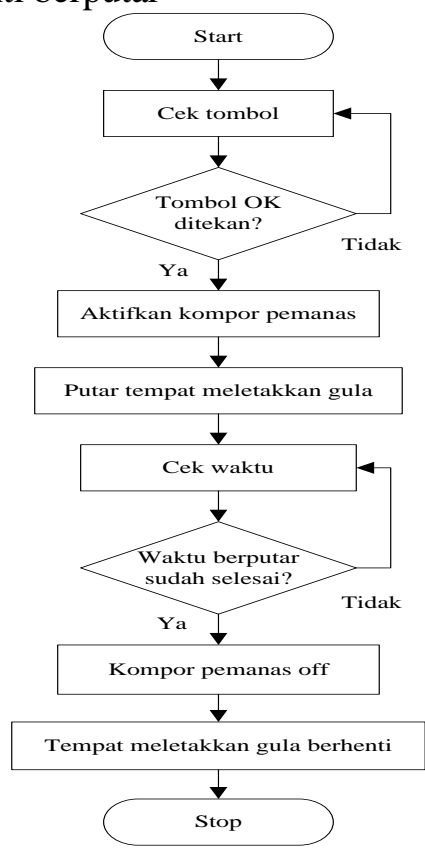

Gambar 9. Flowchart Kerja Sistem 
C. Flowchart Alir Program

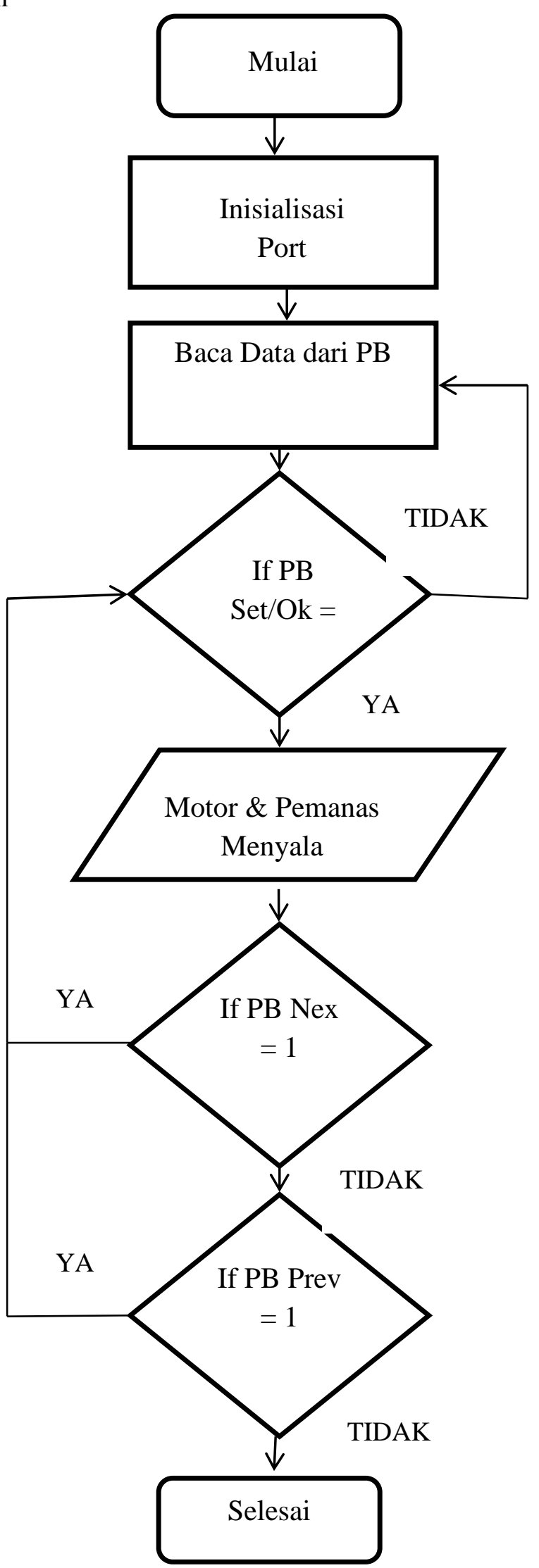

Gambar 10. Flowchart Alir Program

Berdasarkan gambar flowchart tersebut menunjukan proses kerja yang berada didalam mikrokontroler arduino uno. mulai merupakan suatu tanda bahwa alat mendapatkan daya untuk menghidupkan sistem. Setelah itu menuju inisialisasi port yang merupakan memuat data 
pemrograman dari arduino, sensor suhu, LCD, I2C, dan motor AC. Jika push button set/ok memberi input data, maka motor dan pemanas menyala, kemudian jika push button set/ok tidak menyala maka baca data dari PB dahulu. Jika push button nex memberi input data maka akan kembali ke PB set/ok dan jika push button prev memberi input data maka akan kembali ke PB set/ok dan pemanas dan motor akan menyala.

D. Metode Penelitian

Metode dari penelitian ini adalah merancang sebuah alat pembuat permen kapas secara otomatis menggunakan mikrokontroller, alat ini diset berdasarkan waktu dan takaran gula untuk menentukan ukuran permen kapas yaiu besar, sedang dan kecil.

\section{PENGUJIAN ALAT}

A. Pengujian Tombol dan tampilan LCD

Sebelum melakukan pengujian display LCD dan tombol ada beberapa prosedur yang harus dilakukan terlebih dulu

1. Siapkan modul Arduino Uno untuk memberi perintah kepada display LCD dan menerima logika dari tombol

2. Siapkan display LCD untuk menampilkan informasi

3. Siapkan 3 buah tombol untuk memilih ukuran permen kapas dan OK

4. Hubungkan display LCD ke pin A4 dan A5 modul Arduino Uno

5. Hubungkan tombol ke pin 5, 6, dan 7 modul Arduino Uno

Pengujian dilakukan dengan membuat program untuk menampilkan informasi di display LCD

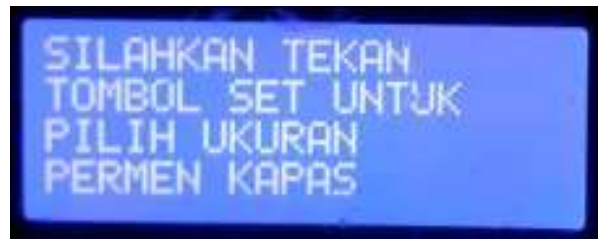

Gambar 11. Tampilan LCD pemilihan Ukuran Kapas

Dari tampilan LCD dibuatlah tabel pengujian untuk takaran gula $1 / 2$ sendok, 1 sendok dan 1,5 sendok, terdapat pada tabel 1, 2 dan 3 .

Tabel 1. Pengujian waktu Takaran Gula 1/2 Sendok

\begin{tabular}{|c|c|c|c|c|c|c|}
\hline Pengujian ke & Massa Gula (m) & $\begin{array}{c}\text { Kalor } \\
\text { Jenis (c) }\end{array}$ & Waktu & $\mathrm{T} 1$ & $\mathrm{~T} 2$ & T1-T2 \\
\hline 1 & 7 gram & $450 \mathrm{j} / \mathrm{kg}$ & $60 \mathrm{dtk}$ & $54^{\circ} \mathrm{C}$ & $58^{\circ} \mathrm{C}$ & $4^{\circ} \mathrm{C}$ \\
\hline 2 & 7 gram & $450 \mathrm{j} / \mathrm{kg}$ & $90 \mathrm{dtk}$ & $54^{\circ} \mathrm{C}$ & $60^{\circ} \mathrm{C}$ & $6^{\circ} \mathrm{C}$ \\
\hline 3 & 7 gram & $450 \mathrm{j} / \mathrm{kg}$ & $120 \mathrm{dtk}$ & $54^{\circ} \mathrm{C}$ & $62^{\circ} \mathrm{C}$ & $8^{\circ} \mathrm{C}$ \\
\hline 4 & 7 gram & $450 \mathrm{j} / \mathrm{kg}$ & $150 \mathrm{dtk}$ & $54^{\circ} \mathrm{C}$ & $64^{\circ} \mathrm{C}$ & $10^{\circ} \mathrm{C}$ \\
\hline 5 & 7 gram & $450 \mathrm{j} / \mathrm{kg}$ & $180 \mathrm{dtk}$ & $54^{\circ} \mathrm{C}$ & $66^{\circ} \mathrm{C}$ & $12^{\circ} \mathrm{C}$ \\
\hline \multicolumn{3}{|c|}{ Rata-Rata } & $120 \mathrm{dtk}$ & $54^{\circ} \mathrm{C}$ & $62^{\circ} \mathrm{C}$ & $8^{\circ} \mathrm{C}$ \\
\hline
\end{tabular}


- Table 2. Pengujian waktu Takaran Gula 1 Sendok

\begin{tabular}{|c|c|c|c|c|c|c|}
\hline Pengujian ke & Massa Gula (m) & $\begin{array}{l}\text { Kalor } \\
\text { Jenis (c) }\end{array}$ & Waktu & $\mathrm{T} 1$ & $\mathrm{~T} 2$ & $\mathrm{~T} 1-\mathrm{T} 2$ \\
\hline 1 & 14 gram & $450 \mathrm{j} / \mathrm{kg}$ & $90 \mathrm{dtk}$ & $64^{\circ} \mathrm{C}$ & $70^{\circ} \mathrm{C}$ & $6^{\circ} \mathrm{C}$ \\
\hline 2 & 14 gram & $450 \mathrm{j} / \mathrm{kg}$ & $100 \mathrm{dtk}$ & $64^{\circ} \mathrm{C}$ & $73^{\circ} \mathrm{C}$ & $9^{\circ} \mathrm{C}$ \\
\hline 3 & 14 gram & $450 \mathrm{j} / \mathrm{kg}$ & $150 \mathrm{dtk}$ & $64^{\circ} \mathrm{C}$ & $75^{\circ} \mathrm{C}$ & $11^{\circ} \mathrm{C}$ \\
\hline 4 & 14 gram & $450 \mathrm{j} / \mathrm{kg}$ & $180 \mathrm{dtk}$ & $64^{\circ} \mathrm{C}$ & $77^{\circ} \mathrm{C}$ & $13^{\circ} \mathrm{C}$ \\
\hline 5 & 14 gram & $450 \mathrm{j} / \mathrm{kg}$ & $210 \mathrm{dtk}$ & $64^{\circ} \mathrm{C}$ & $79^{\circ} \mathrm{C}$ & $15^{\circ} \mathrm{C}$ \\
\hline \multicolumn{3}{|c|}{ Rata-Rata } & $150 \mathrm{dtk}$ & $64^{\circ} \mathrm{C}$ & $74,8^{\circ} \mathrm{C}$ & $10,8^{\circ} \mathrm{C}$ \\
\hline
\end{tabular}

Tabel 3. Pengujian waktu Takaran Gula 1,5 Sendok

\begin{tabular}{|c|c|c|c|c|c|c|}
\hline $\begin{array}{c}\text { Pengujian } \\
\text { ke }\end{array}$ & Massa Gula (m) & $\begin{array}{l}\text { Kalor Jenis } \\
\text { (c) }\end{array}$ & Waktu & $\begin{array}{l}\text { Suhu } \\
\text { (T1) }\end{array}$ & $\begin{array}{l}\text { Suhu } \\
\text { (T2) }\end{array}$ & $\mathrm{T} 2-\mathrm{T} 1$ \\
\hline 1 & 21 gram & $450 \mathrm{j} / \mathrm{kg}{ }^{\circ} \mathrm{C}$ & $120 \mathrm{dtk}$ & $66^{\circ} \mathrm{C}$ & $74^{\circ} \mathrm{C}$ & $8^{\circ} \mathrm{C}$ \\
\hline 2 & 21 gram & $450 \mathrm{j} / \mathrm{kg}{ }^{\circ} \mathrm{C}$ & $150 \mathrm{dtk}$ & $66^{\circ} \mathrm{C}$ & $76^{\circ} \mathrm{C}$ & $10^{\circ} \mathrm{C}$ \\
\hline 3 & 21 gram & $450 \mathrm{j} / \mathrm{kg}{ }^{\circ} \mathrm{C}$ & $180 \mathrm{dtk}$ & $66^{\circ} \mathrm{C}$ & $78^{\circ} \mathrm{C}$ & $12^{\circ} \mathrm{C}$ \\
\hline 4 & 21 gram & $450 \mathrm{j} / \mathrm{kg}{ }^{\circ} \mathrm{C}$ & $210 \mathrm{dtk}$ & $66^{\circ} \mathrm{C}$ & $79^{\circ} \mathrm{C}$ & $13^{\circ} \mathrm{C}$ \\
\hline 5 & 21 gram & $450 \mathrm{j} / \mathrm{kg}{ }^{\circ} \mathrm{C}$ & $240 \mathrm{dtk}$ & $66^{\circ} \mathrm{C}$ & $79^{\circ} \mathrm{C}$ & $13^{\circ} \mathrm{C}$ \\
\hline \multicolumn{3}{|c|}{ Rata - Rata } & $180 \mathrm{dtk}$ & $66^{\circ} \mathrm{C}$ & $77,2^{\circ} \mathrm{C}$ & $11,2^{\circ} \mathrm{C}$ \\
\hline
\end{tabular}

B. Pengumpulan Data dan Hasil Analisa

Pengumpulan data penelitian menggunakan teknik observasi melalaui hasil penelitian dengan beberapa percobaan menggunakan 3 takaran gula yaitu: 1/2 sendok gula, 1 sendok gula, dan 1 1/2 gula.dengan menggunakan termometer yang berperan untuk mengetahui temperatur actual pada pemanas dengan suhu yang berda pada LCD. Berdasarkan hasil penelitian yang telah dilakukan, dengan menggunakan beberapa takaran gula menghasilkan data sebagai berikut :

- Tabel 4. Pengujian Alat Takaran Gula 1/2 Sendok

\begin{tabular}{|c|c|c|c|c|}
\hline Pengujian ke & waktu & $\begin{array}{c}\text { Suhu awal } \\
\text { pemanas }\end{array}$ & $\begin{array}{c}\text { Suhu akhir } \\
\text { pemanas }\end{array}$ & Hasil \\
\hline 1 & 2 menit & $30^{\circ} \mathrm{C}$ & $54^{\circ} \mathrm{C}$ & Tdk \\
\hline 2 & 2 menit & $30^{\circ} \mathrm{C}$ & $64^{\circ} \mathrm{C}$ & Ok \\
\hline 3 & 2 menit & $30^{\circ} \mathrm{C}$ & $63^{\circ} \mathrm{C}$ & Ok \\
\hline 4 & 2 menit & $30^{\circ} \mathrm{C}$ & $70^{\circ} \mathrm{C}$ & Ok \\
\hline 5 & 2 menit & $30^{\circ} \mathrm{C}$ & $70^{\circ} \mathrm{C}$ & Ok \\
\hline Rata-rata & $54,5^{\circ} \mathrm{C}$ & $64,8^{\circ} \mathrm{C}$ & $\begin{array}{c}\text { Hasil Ok } \\
\text { pada2menit ke } \\
2\end{array}$ \\
\hline
\end{tabular}


Tabel 5. Pengujian Alat Takaran Gula 1 Sendok

\begin{tabular}{|c|c|c|c|c|}
\hline Pengujian ke & waktu & $\begin{array}{c}\text { Suhu } \\
\text { awal } \\
\text { pemanas }\end{array}$ & $\begin{array}{c}\text { Suhu akhir } \\
\text { pemanas }\end{array}$ & Hasil \\
\hline 1 & 2,5 menit & $64^{\circ} \mathrm{C}$ & $73^{\circ} \mathrm{C}$ & Ok \\
\hline 2 & 2,5 menit & $64^{\circ} \mathrm{C}$ & $73^{\circ} \mathrm{C}$ & Ok \\
\hline 3 & 2,5 menit & $64^{\circ} \mathrm{C}$ & $74^{\circ} \mathrm{C}$ & Ok \\
\hline 4 & 2,5 menit & $64^{\circ} \mathrm{C}$ & $75^{\circ} \mathrm{C}$ & Ok \\
\hline 5 & 2,5 menit & $64^{\circ} \mathrm{C}$ & $76^{\circ} \mathrm{C}$ & Ok \\
\hline Rata-rata & $68,8^{\circ} \mathrm{C}$ & $64,8^{\circ} \mathrm{C}$ & $\begin{array}{c}\text { Hasil Ok, pada } \\
\text { setiap 2,5 } \\
\text { menit }\end{array}$ \\
\hline
\end{tabular}

Tabel 6. Pengujian Alat Takaran Gula 1,5 Sendok

\begin{tabular}{|c|c|c|c|c|}
\hline Pengujian ke & waktu & $\begin{array}{c}\text { Suhu awal } \\
\text { pemanas }\end{array}$ & $\begin{array}{c}\text { Suhu akhir } \\
\text { pemanas }\end{array}$ & Hasil \\
\hline 1 & 3 menit & $70^{\circ} \mathrm{C}$ & $77^{\circ} \mathrm{C}$ & Ok \\
\hline 2 & 3 menit & $70^{\circ} \mathrm{C}$ & $75^{\circ} \mathrm{C}$ & Ok \\
\hline 3 & 3 menit & $70^{\circ} \mathrm{C}$ & $78^{\circ} \mathrm{C}$ & Ok \\
\hline 4 & 3 menit & $70^{\circ} \mathrm{C}$ & $78^{\circ} \mathrm{C}$ & Ok \\
\hline 5 & 3 menit & $70^{\circ} \mathrm{C}$ & $79^{\circ} \mathrm{C}$ & Ok \\
\hline Rata-rata & & $70,4^{\circ} \mathrm{C}$ & $77,4^{\circ} \mathrm{C}$ & $\begin{array}{c}\text { Hasil Ok, pada } \\
\text { setiap 3 menit }\end{array}$ \\
\hline
\end{tabular}

C. Perancangan Keseluruhan

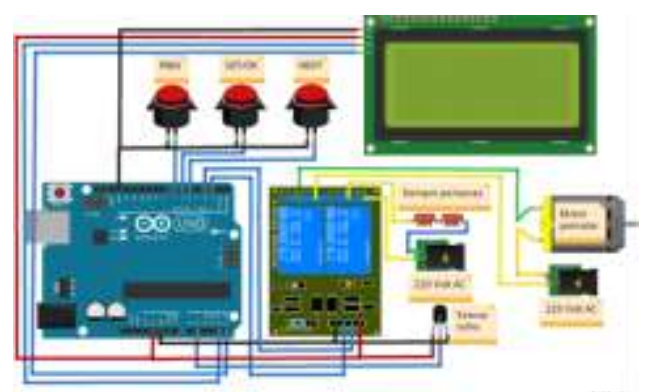

Gambar 12. Perancangan Sistem Keseluruhan

Penjelasan dari gambar diatas :

1. Display LCD ini berkomunikasi dengan Arduino Uno melalui komunikasi I2C sehingga dapat menghemat penggunaan port input output

2. 3 buah tombol terhubung ke pin 5, 6 dan 7 digunakan untuk set lama waktu berputarnya lalu berhenti setelah selesai

3. Kompor pemanas terhubung ke Arduino Uno melalui relay sehingga kompor pemanas dapat dikendalikan oleh arduino uno secara otomatis sesuai dengan listing program yang sudah tersimpan di memori arduino uno

4. Sensor pendeteksi suhu menggunakan LM35 yang terhubung ke Pin A1 yaitu Pin Analog to Digital Converter sehingga tegangan yang dihasilkan sensor dapat dikenali oleh Arduino Uno.

5. Motor pemutar terhubung dengan Arduino uno melalui relay supaya Arduino dapat menjalankan motor dan menghentikan motor secara otomatis sesuai dengan listing program yang sudah tersimpan dalam memori Arduino uno.

6. Motor pemutar mulai berputar setelah kompor pemanas menyala. 


\section{KESIMPULAN}

Berdasarkan hasil penelitian dan pengujian maka dapat diambil beberapa kesimpulan sebagai berikut

1. Pengujian dengan menggunakan takaran gula $1 / 2$ sendok, didapatkan suhu awal rata-rata $\left(54,5^{\circ} \mathrm{C}\right)$ dan suhu akhir rata-rata $\left(64,8^{\circ} \mathrm{C}\right)$. Pengujian menggunakan takaran gula 1 sendok, suhu awal pemanas dengan rata-rata $\left(68,8^{\circ} \mathrm{C}\right)$ suhu akhir rata-rata $\left(74,2^{\circ} \mathrm{C}\right)$. Kemudian pada pengujian dengan menggunakan takaran gula $11 / 2$ sendok, suhu awal pemanas dengan ratarata $\left(70,4^{\circ} \mathrm{C}\right)$ suhu akhir pemanas rata-rata $(77,4)$.

2. Agar alat ini bekerja dengan baik, alat ini membutuhkan waktu untuk memanaskan kompor pemanas dalam waktu kurang lebih 2 menit untuk mencapai suhu $\left(54^{\circ} \mathrm{C}\right)$ setelah itu alat ini dapat bekerja secara normal. Hasil mulai terlihat pada sekitar 1 menit dari awal memasukan gula.

3. Pengujian untuk mengetahui waktu yang tepat dari setiap takaran gula. seperti pada takaran gula $1 / 2$ sendok diperoleh rata-rata waktu (120 detik), takaran gula 1 sendok (150 detik) dan pada takarang gula 1 1/2 (180 detik).

4. Penelitian diterapkan untuk pembuatan permen kapas secara otomatis dengan 3 jenis ukuran yaitu kecil, sedang dan besar, masing-masing telah diset waktu pembuatan permen kapas dan takaran gulanya.

\section{DAFTAR PUSTAKA}

[1]. Bishop, Owen. 2004. Dasar-dasar Elektronika. Jakarta: Erlangga.

[2]. Budiarto, Widodo, 2005. Perancangan Sistem dan Aplikasi Mikrokontroller.Jakarta: PT. Elex Media Komputindo.

[3]. Daryanto, Drs. 2014. Konsep Dasar Teknik Elektronika Kelistrika. Bandung: Alfabeta.

[4]. Fungsi Adaptor. Diakses Pada Tanggal 15 Desember 2019 disitus. http://www.masputz.com/2015/08/pengertian-adaptor-fungsi-dan-jenis.html

[5]. Gambar I2C. Diakses Pada Tanggal 2 Desember 2019 disitus. http://cicuitbasics.com/basicof-the-i2c-comunication-protocol

[6]. Gambar Motor AC. Diakses Pada Tanggal 2 Desember 2019 disitus. http://zonaelektro.net/motor-ac/

[7]. Kadir, Abdul. 2017. Pemrograman Arduino \& Processing. Jakarta: PT. Elex Media Komputindo.

[8]. Saludin, Muis Dr. Ir. M.Kom. 2012. Prinsip Kerja LCD dan Pembuatannya (Liquid Crystal Display). Jakarta: Graha Ilmu.

[9]. Saleh Muhammad . 2017. Rancang Bangun Sisitem Keamanan Rumah Menggunakan Relay. Universitas Suryadarma Jakarta.

[10]. Suswanto. 2015. Perpindahan Panas Pada Heat Exchanger Dobel Pipa Dengan Sirip Berbentuk Siku Empat. Universitas Pancasakti Tegal.

[11]. Zhulkarnaen, Yukovany. 2013. Perancangan dan Pembuatan Pemanas Induksi Dengan Metode Puncake Coil Berbasis Mikrokontroller Atmega 8535. Universitas Brawijaya Malang. 